\title{
NEO-OTTOMANISME DAN ISU HAGIA SOPHIA DIGITAL RELIGION DAN PENGARUH POPULARITAS ERDOGAN TERHADAP KAUM MILENIAL ISLAMIS DI INDONESIA
}

\author{
Bubun Nursya'ban \\ Pascasarjana, Universitas Islam Negeri Sunan Kalijaga Yogyakarta \\ bung.burhanudin17@gmail.com
}

\begin{abstract}
This article aims to discuss how Turkey after the collapse of the Ottoman Empire which the author focused on the appointment of Erdogan as president, the actions of the Turkish political style in promoting Turkey with its political Islamism led to the ideology of Neoottomanism, which is a Turkish culture in the sultanate of the Islamic empire marked by The "conquest" of the Hagia Sophia Byzantium Empire which has now been hotly discussed in cyberspace and the spirit of the return of Islamic order to the pro-caliphate Muslim community in Indonesia with the emergence of various communities of studies on the caliphate and Turkey by several religious leaders, groups and communities of Erdogan lovers as the embodiment of the longedfor leader and enthusiasm of the Muslim community. Actors resulting from developments in the digital era have become unfocused between the pro-sultanate and the Ikhwanul Muslimin network which are increasingly developing into new movements. To analyze this phenomenon, the researcher relies on the concept of digital religion by Heidi A. Campbell on the formation of a community or group which is increasingly in demand among Indonesian Muslims with various motives. The results show that the spirit of neo-ottomanism and the popularity of Erdogan in Indonesia are formed by the network community and formed into the social media community divided into several groups, some are just fans of Erdogan, some have the spirit of manifesting Neo-Ottomanism and some are even classified as radicalism. On the basis of a common vision to realize an Islamic order from both the community and Islamic political parties, the message of neo-ottomanism is very popular among pro-caliphate Muslims in Indonesia.
\end{abstract}

Kata Kunci: Religion; Erdogan; Hagia Sophia; Neo-Ottomanisme 


\section{Abstrak}

Artikel ini bertujuan untuk membahas bagaimana Turki pasca runtuhnya kekaisaran ottoman yang memfokuskan pada pengangkatan Erdogan sebagai presiden, sepak terjang gaya politik Turki dalam mempromosikan Turki dengan politik Islamismenya mengarah pada ideologi Neo-ottomanisme yang merupakan sebuah kultur budaya Turki pada pemerintahan kesultanan kekaisaran Islam ditandai dengan "penaklukan" Hagia Sophia kekaisaran Byzantium yang kini telah hangat diperbincangkan di dunia maya serta menjamur semangat kembalinya tatanan keIslaman kepada masyarakat muslim pro-khilafah di Indonesia dengan munculnya berbagai komunitas kajian-kajian tentang khilafah dan Turki pada beberapa pemuka agama, kelompok dan komunitas pecinta Erdogan sebagai perwujudan pemimpin yang dirindukan serta antusiasme masyarakat muslim. Aktor yang dihasilkan dari perkembangan di era digital menjadi tidak terfokus antara prokesultanan dengan jaringan Ikhwanul Muslimin yang semakin hari berkembang menjadi pergerakan baru. Untuk menganalisis fenomena tersebut, artikel ini menyandarkan konsep digital religion Heidi A. Campbell terhadap terbentuknya komunitas atau kelompok yang semakin hari semakin banyak diminati dikalangan muslim Indonesia dengan motif yang bervariasi. Hasil temuan dari artikel ini menunjukan bahwa semangat neo-ottomanisme dan popularitas Erdogan di Indonesia terbentuk oleh masyarakat jaringan dan terbentuk kedalam komunitas media sosial terbagi kedalam beberapa golongan, ada yang sekedar penggemar Erdogan, ada pula yang memiliki semangat terwujudnya Neo-Ottomanisme bahkan ada pula yang tergolong kepada paham radikalisme. Atas dasar kesamaan visi untuk mewujudkan tatanan keIslaman baik dari kalangan komunitas atau partai politik Islam maka pesan neo-ottomanisme sangat di gemari oleh kalangan muslim pro-khilafah di Indonesia.

Kata Kunci: Religion; Erdogan; Hagia Sophia; Neo-Ottomanisme 


\section{A. Pendahuluan}

Pada era digitalisasi, internet dapat berperan aktif dalam menyampaikan pesan dari belahan dunia manapun seperti beberapa bulan terakhir dunia seakan dihebohkan dengan sebuah kebijakan sensitif yang dilakukan oleh pemerintahan Turki dengan konversi Hagia Sophia yang semula digunakan sebagai Museum menjadi sebuah masjid aktif bagi umat Islam. Hagia Sophia atau dikenal dengan Aya Sophia kini telah menjadi saksi bisu kekacauan manusia selama 1500 tahun terakhir. Setidaknya bangunan tersebut telah merekam banyak peristiwa dari berbagai ummat beragama seperti Umat Kristen Ortodoks, Katolik, Muslim, hingga sekularisasi yang menambah 'warna' pada bangunan megah di Istanbul ini. Hagia Sophia kembali mengalami kekacauan lagi setelah 85 tahun menjadi museum, pasalnya, pengadilan Turki mengubah statusnya kembali menjadi masjid pada 10 Juli 2020. Dua minggu kemudian, bangunan bersejarah tersebut resmi dibuka sebagai tempat ibadah umat Islam. Presiden Recep Tayyip Erdogan pada saat itu menghadiri peresmian pembukaan tempat ibadah umat muslim serta menghadiri shalat Jumat. ${ }^{1}$

Keputusan konversi Hagia Sophia ini mendapat tanggapan dari berbagai negara dan pemuka agama, mulai dari masyarakat biasa hingga pejabat pemerintah. Beberapa negara mayoritas Muslim mendukung keputusan otoritas Turki untuk mengubah Hagia Sophia menjadi Masjid. Banyak organisasi Muslim, seperti Maghrib Arab Union, Ikhwanul Muslimin serta mayoritas muslim di Indonesia mendukung keputusan tersebut. ${ }^{2}$

${ }^{1}$ Isil Sariyuce and Emma Reynolds, (2020, 26 Juli) Turkey's Erdogan orders the conversion of Hagia Sophia back into a mosque, CNN Diakses dari: https://edition.cnn.com/2020/07/10/europe/hagia-sophia-mosque-turkeyintl/index.html

${ }^{2}$ Umi Qodarsasi, Melina Nurul Khofifah, Hagia Sophia dan Kebangkitan Politik Islam di Turki, Institut Agama Islam Negeri (IAIN) Kudus, 2020. 
Selain respon positif keputusan tersebut mendapat kritik terutama bagi kelompok sekuler, menurutnya Hagia Sophia harus tetap menjadi museum sebagai simbol solidaritas Kristen dan Muslim. ${ }^{3}$ Kritik lain datang dari beberapa pihak termasuk UNESCO, Yunani, Amerika Serikat dan Uni Eropa telah mengkritik kebijakan Erdogan. UNESCO mengatakan Hagia Sophia adalah bagian dari distrik bersejarah bagi Istanbul dan terdaftar sebagai museum Warisan Dunia UNESCO. Pada saat yang sama, Yunani yang memiliki lokasi geografis yang dekat dengan Turki mengkritik keras atas keputusan Erdogan dan menambah ketegangan diantara kedua negara, Yunani menganggap bahwa Hagia Sophia merupakan pusat Gereja Ortodoks tempat kekaisaran Byzantium dilantik dan di sucikan. ${ }^{4}$

Pada sejarahnya bangunan Hagia Sophia pertamakali dibangun oleh Kaisar Justinian pada tahun 537 sebagai Katedral Konstantinopel, dan pada tahun 1453 oleh Sultan Muhammad alfatih (Sultan Mehmet II) diubah menjadi Masjid Aya Sofya, kemudian menjadi sebuah museum pada tahun 1934 atas dorongan dari Mustafa Kemal. ${ }^{5}$

Peresmian konversi Hagia Sophia tersebut menimbulkan masalah dan perdebatan diantara para peneliti, politisi, pemuka agama serta sejarawan dan dianggap memanjakan muslim konservatif. Pro kontra atas konversi Hagia Sophia yang memiliki latar belakang sejarah yang panjang serta banyak dibicarakan pada buku dan jurnal tersebut telah memicu anggapan sentimentil terhadap pemerintahan Turki akan Islamismenya.

\footnotetext{
${ }^{3}$ Kompas.com Turki Resmi Jadikan Hagia Sophia Masjid, Negara-Negara Ini Menentang, 11 juli 2020. Diakses pada: https://www.kompas.tv/article/93130/turki-resmi-jadikan-hagia-sophia-masjidnegara-negara-ini menetang\#: :text=KOMPAS.TV\%20\%2D\%20Presiden\%20Turki\%2C,museu m\%20yang\%20dikeluarkan\%20pada\%201935.

${ }^{4}$ Eka Yudha (Minggu, 26 Juli 2020 ) Turkidan Yunani Saling Sindir Usai Salat Jumat di Hagia Sophia. (2020). Diakses dari: https://dunia.tempo.co/read/1369340/Turki-dan-yunani-saling-sindir-usaisalat-jumat-di-hagia-sophia

${ }^{5}$ Cohen, Andrew Jonathan, Tesis: Arsitektur dalam Agama: Sejarah Hagia Sophia dan proposal untuk Mengembalikannya ke Ibadah (Universitas Internasional Florida, 2011), 1.
} 
Walaupun demikian Erdogan yang mendapat tekanan internasional dan dianggap meragukan penerapan sistem demokrasi Turki pasca gagalnya kudeta pada tahun 2017, bagi kalangan muslim sendiri Turki melalui Presiden Erdogan menjadi harapan baru kebangkitan peradaban Islam. ${ }^{6}$

Menurut Muhammad suryadi syarif dkk dalam junalnya ${ }^{7}$ menyebutkan setidaknya terdapat empat teori yang mencoba di dobrak oleh pemerintahan Turki dalam konversi Hagia Sophia tersebut antara lain teori modernisme, teori warisan budaya (museum), teori sekularisme \& laicite, dan teori historiografi. Teori modernisme menjelaskan diplomasi intelektual Hagia Sophia, teori warisan budaya (museum) menjelaskan latar belakang teori mengapa Hagia Sophia sebagai bangunan museum yang merupakan keputusan terbaik bagi umat manusia di dunia, terlepas dari apa yang ada dalam keputusan Presiden Turki 10 Juli 2020 yang lalu. Kemudian teori sekularisme \& laicite teori yang menganalisa seperti apa inward looking orang Turki saat ini dan Historiografinya akan menjelaskan pentingnya Hagia Sophia bagi sejarah dunia, termasuk sejarah Islam. Imbas dari kebijakan tersebut Turki terancam kehilangan sejarah ikonik yang tertanam pada bangunan megah Hagia Sophia dimata dunia.

Arus informasi dan komunikasi pada era digital mengubah pandangan beberapa komunitas di Indonesia mengenai terlebih lagi mengenai konversi Hagia Sophia dan mendapatkan respon serta antusias dari beberapa kalangan peneliti ataupun dari kelompok dan komunitas muslim. Tidak dipungkiri lagi bahwa proses westernisasi dan sekularisasi Ataturk pada saat ini bisa dibilang tidak berhasil secara keseluruhan sebab Turki yang semula menerapkan sekularisme dianggap sebagai penerapan secara instan, karena cenderung dipaksakan oleh Mustafa Kemal Attaturk tanpa ada proses alamiah dari rakyat dan penopang modernisasi yaitu sekularisme dan nasionalisme murni. ${ }^{8}$

\footnotetext{
${ }^{6}$ Puspitarini, R. C. Kaylan Kebljakan Polltlk Internaslonal: Metode, Teoz1 \& StUdl Kasus (Surabaya: CV. Jakad Media Publishing, 2020).

7 Mohammad Suryadi Syarif, dkk., Jurnal "Indonesian Perspective on Hagia Sophia” Dosen studi Pascasarjana di Universitas Muhammadiyah 2020.

${ }^{8}$ Kamilah. "Peranan Mustafa Kemal Ataturk dalam Modernisasi Turki Tahun 1923-1938” 2011.
} 
Berbeda dengan kebangkitan sekularisasi Eropa yang dilandasi oleh gerakan melawan hegemoni gereja, gerakan sekulerisme di Eropa merupakan kesadaran kolektif yang dibentuk oleh elit dan masyarakat, sedangkan sekularisasi Ataturk masyarakat masih dalam pengaruh Osmani yang masih kuat. ${ }^{9}$ Akibat gejolak antara de facto dan de jure ini, sekularisme Turki menjadi seperti keadaan di negara Indonesia. Menurut profesor Munawir Syadzali, Indonesia bukanlah negara yang religius juga bukan negara Islam akan tetapi terkadang perlawanan rakyat Indonesia terhadap pemerintahannya sama persis dengan perlawanan rakyat Turki terhadap pemerintahannya dengan hegemoni Islamisme yang sangat kuat baik di kalangan masyarakat ataupun elit politiknya. ${ }^{10}$

Peran media dalam menyampaikan narasi konversi Hagia Sophia menjadi sebuah Masjid pada media Indonesia baik pada pemberitaan nasional atau pada media-media masa sangat tidak terbendung terlebih di era digitalisasi segala sesuatu membutuhkan layanan internet dengan kata lain manusia hidup dalam dua dimensi, dunia maya dan dunia nyata. Begitupula dengan politik, bidang politik merupakan bidang yang membutuhkan dakwah publikasi, sehingga internet merupakan media yang banyak digunakan dalam mempromosikan tokoh politik atau partai politik. Oleh karena itu, peran media internet tidak dapat dipisahkan. Popularitas karakter digital di dunia maya merupakan cerminan awal dari popularitas mereka di dunia nyata. $^{11}$

Beberapa komunitas di media massa menyampaikan pemberitaan tentang Turki dan Erdogan yang mengarah pada keunikan kepemimpinan yang diharapkan oleh sebagian besar umat Islam di Indonesia, sebagai perwujudan ekspresi pemimpin Kesultanan pada masa Khilafah.

\footnotetext{
${ }^{9}$ M. Arfan Mu'ammar "Kritik Terhadap Sekularisasi Turki Telaah Historis Transformasi Turki Usmani" 2016 Pascasarjana Universitas Muhammadiyah Surabaya.

10 M. Arfan Mu'ammar "Kritik Terhadap Sekularisasi Turki Telaah Historis Transformasi Turki Usmani" 2016 Pascasarjana Universitas Muhammadiyah Surabaya, 3.

${ }^{11}$ Situmorang, J. R, "Pemanfaatan Internet sebagai New Media dalam bidang Politik, Bisnis, Pendidikan dan Sosial Budaya," Jurnal Administrasi Bisnis, Vol. 8, No.1, 2012.
} 
Media masa kini telah menjelma sebagai rumah bagi pecinta Erdogan dan ke khalifahan diantaranya komunitas yang mereka namai "sahabat Erdogan" pada laman facebook atau IG @ sahabatErdogan dengan jumlah followers 17,7 ribu dan jumlah postingan sebanyak 788 , beberapa postingan mengarah pada pengidolaan terhadap Erdogan dengan membandingkannya dengan Sultan pada masa kekhalifahan seperti dikutip dari Anadolu (kantor berita resmi Turki) komunitas sahabat Erdogan didirikan untuk mempererat hubungan persaudaraan antara Indonesia dan Turki. Pendiri sahabat Erdogan Fiqruddin Satyo menyatakan bahwa ide mendirikan komunitas ini berawal dari diskusi di media sosial pada akhir tahun 2014 yang membahas tentang Turki dan Sejarah Turki serta hubungan antara Turki dan Indonesia. ${ }^{12}$

Selain komunitas sahabat Erdogan terdapat pula akunakun yang serupa dengan penamaan yang berbeda seperti Gen saladin @gen.saladin dengan pengikut 198 Ribu dengan postingan 1.334 kali, akun tersebut banyak menceritakan tokohtokoh Islam termasuk tokoh kholifah. Terdapat pula akun halaman Facebook bernama "Sultan Erdogan" yang memiliki massa netizen Facebook hampir ratusan ribu. @sulthonErdogan ini mencapai 168.500 user. Isi postingan "Sultan Erdogan" pun hampir sama dengan membawa informasi terkait aktivitas kenegaraan Erdogan di bawah kepemimpinannya yakni Turki yang berkontribusi di kancah internasional.

Dari berbagai fenomena di atas menyisahkan beberapa pertanyaan mengenai aktivitas kenegaraan Erdogan yang berdampak pada popularitasnya selain dari pada fokus geopolitik dunia yang mulai menempatkan Turki sebagai pemeran baru, terlebih lagi keikutsertaan Turki dalam membela negara-negara mayoritas Islam menempatkan Turki pada posisi pertama di hati mayoritas muslim dunia terutama Indonesia, narasi yang dibangun pun senantiasa memberikan gambaran bahwa Turki era Erdogan telah bertransformasi kembali menjadi lebih Islami.

${ }^{12}$ Nabhan Aiqani, Menguatnya Popularitas Turki di Indonesia: Faktor Ikhwanul Muslimin sebagai Identitas, Kolektif Ilmu Hubungan Internasional Universitas Andalas, 2018. 
Dengan fakta tersebut telah banyak diperbincangkan oleh kalangan muslim di dunia maya yang tergabung dalam kelompok-kelompok media sosial, maka artikel ini mencoba untuk menjawab bagaimana pengaruh politik Turki terhadap kelompok muslim Indonesia yang terafiliasi pada latar belakang yang sama serta penulis juga mencoba untuk mengembangkan bagaimana hubungan media masa pada proses penyebaran paham Ikhwatul Muslimin atau PKS serta paham neo-ottomanisme pada kalangan pemuda yang terjaring pada media masa (online). Sebagai hipotesis awal artikel ini berasumsi bahwa terdapat pola penyebaran yang sengaja dibuat untuk membangun kepercayaan akan kembalinya kejayaan ottoman (kekhalifahan) dan Erdogan sebagai sosok yang diidealkan dalam narasi kebangkitan tersebut. 


\section{B. Tinjauan Pustaka dan Metode Penelitian}

Artikel ini bersumber dari hasil penelitian dengan mengambil referensi dari berbagai sumber seperti skripsi, jurnal, tesis dan penelitian terdahulu sebagai rujukan yang berkaitan dengan tema diatas, Penulisan dalam artikel ini memakai teori dan konsep dengan menggunakan berbagai macam referensi baik dari buku, jurnal, dokumen internet, dan hasil penelitian terdahulu. Rujukan utama penulis untuk memahami dan menjelaskan konsep neo-ottomanisme, Hagia Sophia serta popularitas Erdogan di Indonesia antara lain:

Buku yang disusun oleh Heidi A. Campbell bertema digital religion understanding religious practice in new media worlds (2013). Penelitian yang di tulis oleh Heidi A. Campbell ini mencakup keterlibatan keagamaan dengan berbagai bentuk media baru, menyoroti contoh-contoh dari semua lima agama besar dunia dan gerakan keagamaan baru lainnya.

Artikel ini terperinci menggambarkan sebuah fenomena bagaimana agama digital masuk kedalam sendi sendi jaringan internet mulai dari ponsel dan video game hingga blog dan buku online ini yang memberikan tinjauan rinci tentang masalah yang berkaitan dengan otoritas agama keaslian, komunitas, identitas, dan ritual online mencakup serangkaian studi kasus untuk menggambarkan dan menjelaskan tematik eksplorasi mempertimbangkan masalah teoritis, etika, dan teologis yang diangkat kedalam permasalahan yang ada.

Tulisan ini menggabungkan karya para ahli internasional terkemuka dari disiplin ilmu terutama yang mengenai Perspektif Agama Digital yang berkontribusi sangat berharga bagi para sarjana dan siswa yang menginginkan pengembangan pemahaman yang lebih dalam tentang bidang tersebut.

Heidi A. Campbell adalah Professor Associate of Communication di Texas A\&M University, AS. Dia telah meneliti dan diterbitkan secara ekstensif tentang tema-tema yang berkaitan dengan agama dan Internet selama lebih dari lima belas tahun, berfokus pada perilaku komunitas agama online sebagai kerja komparatif tentang penggunaan internet yang terfokus pada kelompok Yahudi, Muslim, dan Kristen persepsi bentuk media baru. Karyanya yang baru diterbitkan berfokus pada agama Buddha praktik keagamaan dan estetika. 
Jurnal yang di tulis oleh Nabhan Aiqani, (2018) berjudul "Menguatnya Popularitas Turki di Indonesia: Faktor Ikhwanul Muslimin sebagai Identitas Kolektif" Ilmu Hubungan Internasional Universitas Andalas. Artikel ini bertuliskan tentang sebab dan faktor menguatnya popularitas Erdogan Hasil penelitian menunjukkan bahwa menguatnya pengaruh Turki dan Erdogan di Indonesia dikarenakan faktor kesamaan identitas kolektif sebagai Ikhwanul Muslimin antara kelompok Islam di Indonesia yang terafiliasi dalam gerakan politik PKS dengan Turki dibawah pemerintahan politik AKP (Adalet ve Kalkinma Partisi) yang berbasiskan Islamisme. Kesamaan itu terlihat dari Kelompok Islam di Indonesia (PKS dan jejaringnya) yang menjadikan IM sebagai rujukan ideologi maupun strategi gerakan dan faktor Erdogan (bersama AKP) yang memiliki kedekatan historis dan ideologis dengan IM. Sehingga, atas dasar hal tersebut, popularitas Turki (Pemerintahan Erdogan dan AKP) menjadi amat populer di Indonesia melalui aktivitas dan narasi yang dibangun oleh kelompok Islam tersebut.

Penulisan artikel ini bertujuan untuk melanjutkan serta menambah hasil dari penelitian sebelumnya sehingga menjadikan jurnal yang di tulis oleh Nabhan Aiqani ini sebagai rujukan pertama, hal yang akan dilakukan yaitu memperkuat data temuan tentang neo-ottomanisme Turki (keinginan Turki untuk menjadi pemimpin Islam dunia) melalui pengaruh media dan Islamisme terutama terhadap kalangan muda di Indonesia serta mencoba menghubungkannya dengan gerakan pro-khilafah.

Jurnal "Indonesian Perspective on Hagia Sophia" oleh Mohammad Suryadi Syarif dosen studi Pascasarjana di Universitas Muhammadiyah beserta rekannya, tulisan ini memiliki kebaruan tentang narasi tentang Hagia Sophia, karena tidak hanya membahas aspek historis dari Hagia Sophia, tetapi juga menampilkan Hagia Sophia dari perspektif Indonesia; mengapa Hagia Sophia enak dibicarakan oleh orang Indonesia dan mengapa Hagia Sophia menjadi bagian dari identitas Islam Indonesia, termasuk perdebatan intelektual setelah Presiden Turki Recep Tayyip Erdogan mengubah fungsi Hagia Shopia, dari Museum menjadi Masjid, sedangkan Hagia Sophia adalah sumurtujuan museum yang terkenal untuk turis Indonesia. 
Penyajian tulisan pada jurnal disini memiliki empat persfektif teori sehingga membantu bagi penulis atau pembaca untuk dijadikan acuan terlebih objek yang akan coba di teliti mengenai Hagia Sophia yang senter dibicarakan kalangan muslim di Indonesia terutama muslim konservatif yang menginginkan kembalinya masa kejayaan Islam.

Melalui junal tersebut dijadikan pendukung acuan mengenai objek yang diteliti berdasarkan sudut pandang umum yang akan di tarik pada perspektif lain seperti media massa dan gerakan Islamisme lainnya.

Jurnal "Conservative Narrative: A Contemporary NeoOttomanist Approach to Turkish Politics" (2020) yang disusun oleh Umut Uzer. Artikel ini membahas kebijakan dan retorika para pemimpin AKP yang dapat dikategorikan sebagai reinterpretasi masa lalu Ottoman dengan membahas keterkaitan antara sejarah dan konstruksi identitas modern. Kemudian jurnal ini menerangkan mengenai Neo-Ottomanisme dengan menganggap bahwa ottomanisme bukan tentang masa lalu tetapi tentang politik Turki saat ini, serta peta mental mendekonstruksi Republik Kemalis konsepsi identitas dan masyarakat di masa depan. Artikel ini memposisikan jurnal diatas menjadi dasar atau modal awal dalam menerangkan politik Turki dengan gaya neoottomanismenya yang kemudian akan dikaitkan dengan gerakan Islamis Indonesia sebagai bagian model kerangka awal pengaruh kekaisaran ottoman dimasa lalu.

Pembahasan dalam artikel ini menggunakan pendekatan kualitatif dan jenis penelitian ini adalah deskriptif analisis yang digunakan untuk menggambarkan, menganalisa serta menyelidiki suatu permasalahan yang terjadi sehingga mendapatkan hasil akhir dari analisis dengan teori yang jelas. Yang menjadi objek penelitian kualitatif deskriptif analisis ini adalah gerakan Islamisme Turki yang terfokus pada kebijakan Erdogan pada konversi Hagia Sophia serta hegemoni Islamisme pada media sosial di Indonesia. Teknik analisis yang digunakan adalah dengan pengumpulan data, reduksi data serta penarikan kesimpulan. Dalam Pengumpulan data menggunakan teknik penelitian kepustakaan dengan mengumpulkan dari berbagai sumber baik berupa buku, jurnal, pemberitaan online serta literatur dan dokumen-dokumen yang mendukung penelitian. 


\section{Infiltrasi Neo-Ottomanisme Pada Generasi Milenial Dan Media Sosial Indonesia}

Neo-ottomanisme merupakan paham yang menggambarkan politik Islam yang berjaya pada masa kesultanan di Turki dengan membawa kultur dan budaya namun faktor historis membatasi pengaruh dalam kebijakan luar negerinya yang menentukan posisi Turki dimasa sekarang ${ }^{13}$ dimana neo-ottomanisme adalah corak politik Turki saat ini, dengan memperhatikan kebijakan-kebijakan politik luar negeri terlebih pada negara-negara Islam serta semangat mengembalikan histori pada era modern yang memiliki harapan mengembalikan kepemimpinan Islam dunia.

Dengan maraknya sebaran informasi di dunia maya memiliki motif tertentu baik ideologi, politik atau kepentingan lain yang tersembunyi di balik informasi yang di sebar. Timur Tengah telah merasakan dampak dari hal tersebut. New media di Timur Tengah dianggap telah merusak kontrol hegemonik pemerintah atas aliran informasi. Sebagai cikal bakal lahirnya gelombang demonstrasi yang dikenal dengan Arab Spring yang berusaha mengkudeta pemerintah berkuasa.

Dunia maya juga menjadi pintu bagi beberapa kelompok fundamentalis Islam untuk melindungi, memperkuat komunikasi terhadap identitas ganda mereka ${ }^{16}$ dengan memasukan idiologi terhadap konten yang menarik. Pada perjalanannya media massa memperlihatkan bahwa sebuah teknologi baru tidak pernah menghilangkan konteks pertukaran dengan teknologi yang lama, tetapi mensubstitusinya dengan perkembangan yang pesat. ${ }^{17}$

13 Andraina Ary Fericandra, Ambivalensi Implementasi NeoOttomanisme dalam Kebijakan Luar Negeri Turki terhadap Israel (2009-2014), tahun 2016.

${ }^{14}$ Umut Uzer, Conservative Narrative: A Contemporary Neo-Ottomanist Approach to Turkish Politics", 2020.

${ }^{15}$ Hofheinz, A, "The Internet in the Arab World: Playground for Political Liberalization", International Politics and Society, 2005: 78-96.

16 Khatib, L. "Communicating Islamic Fundamentalism as Global Citizenship", Journal of Communication Inquiry, 2004: 389-409.

${ }^{17}$ DiMaggio, P., Hargittai, E., Neuman, W. R., \& Robinson, J. P. "Sosial Implication of the Internet", Annual Reviews, 2001: 307- 336. 
Oleh karena itu, bisa dikatakan bahwa media online mungkin tidak akan bisa menggantikan sepenuhnya bentukbentuk media lama. Berita online tidak akan menghapus berita tradisional, tetapi meningkatkan kekuatannya dengan menggabungkan teknologi internet dengan fungsi media tradisional. ${ }^{18}$ Argumentasi tersebut juga dituturkan oleh Piliang (2009) bahwa media massa online bisa memiliki efek yang sama dengan media massa konvensional meski hanya terjadi lewat dunia maya.

Pertukaran data virtual yang berupa elemen-elemen dasar dalam kesadaran kolektif dapat dirasakan seolah nyata serta memunculkan adanya perasaan yang sama dalam satu komunitas dengan adanya suatu kewajiban moral yang dibuat dengan kesadaran bersama untuk dijalankan.

Pentingnya menyaring suatu konten pada komunitas atau pada suatu media massa sangat diperlukan terlebih bagi generasi milineal yang hendak menemukan jati diri dengan berhijrah. Fenomena gerakan sosial Hijrah menjadi bentuk aksi kolektif yang mengakui pentingnya agama dalam berkehidupan. ${ }^{19}$ Hijrah pada dasarnya adalah ritual pribadi dan sudah mulai bertransformasi menjadi gerakan berkelanjutan bersama. Gerakan hijrah menjadi salah satu gerakan dakwah yang popular dikalangan kaum muda milenial dan kemudian berkembang menjadi Tren sosial yang umum diikuti. ${ }^{20}$

Secara karakteristik generasi milineal merupakan generasi muda muslim yang tidak terikat dengan berbagai cara pandang dalam melihat dunia dimana iman dan modernitas bisa berjalan beriringan. Generasi Muslim Milenial dianggap sebagai pelopor kaum muda Muslim modern.

${ }^{18}$ Santana, S, Jurnalisme Kontemporer (Jakarta: Yayasan Obor Indonesia, 2005).

${ }^{19}$ Saputra, S., Pujiati, \& Simanihuruk, M., Pengemasan Ideologi Dalam Gerakan Hijrah (Studi Kasus Gerakan Komunitas Sahabat Hijrahkuu di Medan), Civic-Culture: Jurnal Ilmu Pendidikan PKn Dan Sosial Budaya, 2020, 4 (1).

${ }^{20}$ Addini, A, Fenomena Gerakan Hijrah di Kalangan Pemuda Muslim Sebagai Mode Sosial. Journal of Islamic Civilization, 1(2), 2019, 109-118. 
Generasi "M" adalah mereka yang membanggakan keyakinan mereka terhadap antusiasme, energik, aktif dan kreatif, tetapi sangat menuntut dan kritis. Keberadaan mereka membentuk sebuah Budaya dengan cara yang "lembut".

Selain itu, pengetahuan terhadap era keemasan peradaban Islam yang didapatkan menjadi salah satu faktor yang memotivasi mereka untuk mengambil peran mereka dalam kehidupan Islam modern, lalu memberikan pendapat dan bukti yang tidak hanya bisa sejalan dengan agama tetapi deangan modernitas. Perkembangan gerakan hijrah pada generasi milenial muslim memiliki konsep diri menjadi individu yang toleran, beragam, dan mampu menghargai perbedaan dan keberagaman membawa peluang besar untuk pengembangan misi Islam moderat di Indonesia. ${ }^{21}$

Akan tetapi ketersediaan informasi keIslaman yang benar sangat di perlukan oleh kalangan generasi milenial dalam mencari jawaban sebab fenomena hijrah telah menjadi fenomena sosial yang menandai bahwa umat manusia berada pada tahap krisis jati diri terutama di kalangan anak muda. Pada tahap itu, seseorang membutuhkan jawabannya yang kemudian melakukan suatu perubahan, dalam hal ini, seseorang mengubah hal-hal yang sesuai dengan batin dan keagamaan.

Konsep hijrah yang paling populer menjadi perjalanan spiritual menuju kesalehan sejati. ${ }^{22}$ Oleh karena itu, hijrah dipandang sebagai proses transformasi keyakinan agama seseorang.

${ }^{21}$ Zulhazmi, A. Z., \& Hastuti, D. A. S, Da'Wa, Muslim Millennials and Social Media. Lentera, 2018, 2(2), 121-138. https://doi.org/10.21093/lentera.v2i2.1235

${ }^{22}$ Duraesa, M. A., \& Ahyar, M, Reproliferation of Islamist Movement in Surakarta: Trajectory and Strategy in The Post Democratization Indonesia. DINIKA: Academic Journal of Islamic Studies, 2019, 4(2), 201-224. https://doi.org/10.22515/dinika.v4i2.1637 
Transformasi hijrah pada dasarnya digambarkan sebagai upaya untuk menyingkirkan nilai yang buruk akan mengarah pada nilai yang lebih baik dari salah menjadi benar. ${ }^{23}$

Dampak paling signifikan Internet terletak pada peningkatan perkembangan di mana individu datang menjalankan lebih banyak otonomi dalam kaitannya dengan otoritas dan institusi formal pada masalah iman kecenderungan penggunaan Internet untuk pembentukan identitas agama serta ekspresi keagamaan melalui media digital pada dasarnya bersifat individual dan personal.

Proses pencarian informasi keagamaan bagi kalangan muslim milenial salah satunya melalui dakwah online atau informasi digital. Tansformasi dakwah di era digital ditandai dengan adanya perkembangan teknologi masa.

Kembali pada isu neo-ottomanisme Turki yang tersebar pada beberapa laman media sosial seperti @ sahabatErdogan yang memposting berita tentang Turki dan Erdogan. Komunitas online tersebut sejauh ini telah memposting 789 dengan jumlah followers mencapai 17,9 ribu.

Hal yang menarik pada komunitas online tersebut jika dilihat dari beberapa postingannya mengenai Turki dimasa lalu yaitu pada masa kesultanan dan di beberapa postingan selanjutnya mengenai kepemimpinan Erdogan serta kebijakankebijakan yang mengarah pada isu sensitif mengenai simbol kekuasaan kesultanan yaitu penaklukan Hagia Sophia paska dikonversi kembali menjadi masjid aktif bagi umat Islam.

Selain komunitas sahabat Erdogan, komunitas online lain yang serupa yaitu komunitas Gen.saladin, secara singkat komunitas dengan jumlah followers 198 ribu tersebut selalu memposting kisah-kisah heroik kepemimpinan Islam luar dan dalam negeri termasuk pada masa kesultanan, di komunitas ini juga memposting keperkasaan pemimpin perang Salahudin AlAyubi hingga Muhammad Al-Fatih.

${ }^{23}$ Yunus, A. H, Hijrah: Pemaknaan dan Alasan Mentransformasikan Diri Secara Spiritual di Kalangan Mahasiswa, Jurnal Emik, 2019, 2(1). 
Infiltrasi isu neo-Ottomanisme terhadap media sosial di kalangan muslim milenial memuncak pada beberapa saat setelah konversi Hagia Sophia menjadi Masjid, hal tersebut dijadikan momentum bagi pemuka agama atau beberapa orang penulis dalam memberitakan fenomena yang menjadi simbol kekuasaan ottoman seperti dilansir pada laman media @Osman Media dengan memberitakan konversi Hagia Sophia dibarengi postingan tentang penaklukan Andalusia, yang tak kalah dengan lamanlaman yang lain@Osman Media juga giat mengampanyekan politik Turki kontemporer. Maka bisa dikatakan jika infiltrasi isu neo-ottomanisme melalui media masa marak ditemukan dengan ciri menampilkan kultur, simbol dan kebijakan politiknya. Maraknya menyebaran informasi tersebut memicu hadirnya otoritas baru yang membentuk individu-individu menjadi budaya yang dihasilkan oleh pesan dakwah media massa. Faktor lain dari mudahnya informasi masuk dan diminati banyak generasi hijrah milenial adalah dengan adanya gerakan Islamisme kolektif yang mencoba membentuk kesamaan kolektif. ${ }^{24}$

\section{Wacana Politik dalam Media Dakwah di Indonesia}

Pada faktanya era new media dapat merusak proses kontrol media otoriter dan menjadikan pers independen mendominasi dalam klaim keputusan dan membangun makna bersama atau membangun narasi sendiri. Ini berarti bahwa wacana yang sedang berlangsung di banyak situs-situs yang berbau paham ottomanisme atau IM tersebut dapat memiliki dampak besar dalam membentuk subjektivitas dan identitas generasi muslim tidak hanya saat ini, tetapi juga di masa depan.

${ }^{24}$ Yunus, A. H, Hijrah: Pemaknaan dan Alasan Mentransformasikan Diri Secara Spiritual di Kalangan Mahasiswa. Jurnal Emik, 2019, 4. 


\section{E. Pengaruh Ikhwanul Muslimin}

Islam dan politik integratif banyak diwujudkan dalam banyak pemikir dan politikus muslim yang memiliki pemikiran dengan pola yang berbeda dari waktu ke waktu, salah satunya adalah Hasan al-Banna yang merupakan pemimpin kebangkitan pemikiran Islam atau pendiri Ikhwanul Muslimin sekilas tentang sejarah masuknya Ikhwanul Muslimin memasuki Turki ketika lingkaran dalam Ikhwanul Muslimin dibentuk pada 1920-an, pada saat yang sama Turki bergerak menuju sistem negara sekuler yang sepenuhnya menyimpang dari sistem ke-Islaman.

Pemerintahan baru "Republik Turki" mengadopsi kebijakan yang membatasi ruang gerak keagamaan pada waktu itu yang dipelopori oleh gagasan Mustafa Kemal. Salah satu kebijakan yang menjadi gerbang masuknya IM yaitu tentang kebijakan penutupan madrasah pada tahun 1924. Kebijakan ini mengakibatkan mahasiswa berpindah dari Turki ke Universitas Al-Azhar untuk melanjutkan pendidikannya di Mesir. ${ }^{25}$

Lokasi sentral Universitas Al-Azhar saat itu adalah pusat pergerakan IM sehingga menjadi basis. Dikatakan bahwa mahasiswa Turki yang pernah belajar di Universitas Al-Azhar pada masa-masa awal memiliki hubungan dekat dengan IM dan berpartisipasi dalam perumusan rencana penggulingan rezim Turki. Selain itu, pemerintah Mesir memberikan dukungan keuangan melalui Kementerian Yayasan. ${ }^{26}$ Kemudian menemukan titik puncak pembaharuan pasca kudeta 27 Mei dimana kondisi sosial dan politik Turki relatif mengalami perubahan.

Gerakan Ikhwanul Muslimin adalah gerakan yang dinamis dan fleksibel. Di mana pun Ikhwanul Muslimin berada, tidak hanya akan berperilaku sebagai organisasi religius semata tapi berkembang sesuai dengan kontruksi politiknya.

${ }^{25}$ Yunus, A. H, Hijrah: Pemaknaan dan Alasan Mentransformasikan Diri Secara Spiritual di Kalangan Mahasiswa. Jurnal Emik, 2019, 4.

${ }^{26}$ Yunus, A. H, Hijrah: Pemaknaan dan Alasan Mentransformasikan Diri Secara Spiritual di Kalangan Mahasiswa. Jurnal Emik, 2019, 4. 
Ikhwanul Muslimin diadopsi dan digunakan oleh banyak tokoh dan organisasi Islam lainnya, keunikan gerakan Ikhwanul Muslimin ini akan memicu berbagai bentuk gerakan di berbagai tempat lain ada yang menjadi partai politik yang bersama-sama mengelola sebuah negara ada pula yang menjadi oposisi dan apa pula sebagai organisasi masyarakat dengan membawa paham Islam universal. $^{27}$

Seperti halnya Turki, ideologi Ikhwanul Muslimin juga mulai merambah pada negara Indonesia melalui beberapa pola transmisi diantaranya melalui pergerakan alumni-alumni pelajar Indonesia di Timur Tengah, buku terjemahan dari internet, kelompok yang menjadi kaki tangan dari Ikhwanul muslimin seperti PKS, HTI dan salafy. ${ }^{28}$ Meskipun mode transmisi gerakan Masuk ke Indonesia tidak bisa dibedakan dari ketiga pola di atas, namun corak dan bentuk gerakan Islam Timur Tengah yang masuk ke Indonesia berbeda dan tidak tunggal. Secara garis besar, corak dan bentuk gerakan tersebut terbagi dalam tiga kategori, yaitu gerakan HTI, gerakan Salafy yang dimotori alumni LIPIA Jakarta, dan gerakan PKS Tarbiyah. ${ }^{29}$

Perkembangan gerakan Tarbiah di Indonesia Terinspirasi oleh ide-ide Hasan al-Banna dapat dilihat melalui tiga perspektif. Tahap pertama, menyebarkan ide melalui buku atau bacaan, ceramah dan seminar pengetahuan. Tahap kedua, melalui kegiatan organisasi sosial telah religius melalui gerakan Tarbiah di kampus. Tahap ketiga adalah mempraktikkan politik melalui aktivisme politik Ini telah terjadi sejak 1998.

Kegiatan Tarbiah atau halaqah selalu dikemas mengikuti perkembangan zaman. Seseorang yang telah masuk pada tahap ketiga baru boleh bergabung bersama Partai Keadilan (19982003), dan akhirnya menjadi PKS pada tahun 2003 sampai sekarang. ${ }^{30}$

${ }^{27}$ Priandoko, "Pengaruh Pemikiran Politik Hasan al-Banna dalam Partai Keadilan Sejahtera Pasca Reformasi di Indonesia Tahun 1998-2014" Fakultas Ilmu Sosial dan Ilmu Politik Universitas Riau, 2015.

${ }^{28}$ Rahman Nurdin Saleh, Arah Politik Gerakan Islam pada DuaZaman: Studi Komparatif antara Ikhwanul Muslimin di Mesir dan Partai Keadilan Sejahtera di Indonesia, 2016.

${ }^{29}$ Rahman Nurdin Saleh, Arah Politik Gerakan Islam pada Dua Zaman: Studi Komparatif antara Ikhwanul Muslimin di Mesir dan Partai Keadilan Sejahtera di Indonesia, 2016, 4.

${ }^{30}$ Bubalo, Anthony, dkk, PKS dan Kembarannya Bergiat Jadi demokrat di Indonesia, Mesir, dan Turki (Jakarta: Komunitas Bambu, 2012), 45. 
Pergerakan selanjutnya yang merupakan bagian dari infiltasi paham Ikhwanul Muslimin adalah adanya kelompok HTI. Dalam buku berjudul Manifesto Hizbut dikemukakan bahwa HTI merupakan partai politik dengan cita-cita menegakan sistem Islam kaffah serta membentuk organisasi yang bertujuan untuk membebaskan umat manusia dari aturan, pemahaman, pemikiran, sistem hukum Thagut dengan menerapkan syariat Islam di seluruh penjuru dunia. HTI berharap Islam menjadi sistem pemerintahan global.

Di saat yang sama, Indonesia dianggap sebagai titik awal untuk membangun cita-cita khilafah Islam. Bagi HTI Indonesia berpotensi menjadi inti kebangkitan kekuatan Islam dunia. ${ }^{31}$

Namun eksistensi HTI dianggap menyimpang dari ideologi bangsa Indonesia yaitu Pancasila dengan pluralismenya tepatnya pada tanggal 19 Juli 2017 pemerintah Indonesia melalui Kementerian Hukum dan HAM secara resmi mencabut status badan hukum ormas Hizbut Tahrir Indonesia (HTI) berdasarkan Surat KepMent Hukum dan HAM Nomor AHU-30.AH.01.08 tahun 2017 tentang pencabutan Keputusan Menteri Hukum dan HAM. $^{32}$ Namun eksistensi nilai-nilai ideologi HTI masih terasa dikalangan masyarakat terutama muslim muda milenial melalui gerakan kajian atau pengajian baik online maupun offline dengan pendekatan tarbiah jamaai' atau personal. Salah satu komunitas atau organisasi yang dekat sekali dengan pesan dakwah HTI adalah Yuk Ngaji dan sudah tersebar di berbagai daerah bahkan aktif di media sosial dengan bingkai yang menarik ala anak muda pada umumnya.

Pergerakan selanjutnya adalah salafy. Kelompok ini memimpikan hidup dalam komunitas Islam pada masa Nabi Muhammad dan Salaf Assaleh. Padahal, Jamaah Salafi sudah ada di Indonesia sejak 1980-an. Sayangnya pemekaran gerakannya tidak terlalu mentereng dan jumlah kader tidak pernah meningkat secara signifikan.

${ }^{31}$ Nafi' Muthohirin, "Radikalisme Islam Dan Pergerakannya Di Media Sosial”, UIN Syarif Hiddayatullah Jakarta, 2015.

${ }^{32}$ Kompas.com 2017, HTI Resmi dibubarkan pemerintah. Diakses dari https://nasional.kompas.com/read/2017/07/19/10180761/hti-resmi-dibubarkanpemerintah? page $=$ all. 
Fokus gerakan ini adalah memposisikan diri sebagai kelompok riset Islam, bukan untuk mengutarakan pendapat tentang politik Islam. $^{33}$ Pergerakan salafy lebih kepada memberikan pembelajaran untuk ummat yang sesuai dengan alquran dan sunnah. Banyak dari kalangan muda yang menanyakan tentang tatacara ibadah sampai dengan hukum kepada ustadz yang mengisi di pengajian tertentu, corak salafy adalah mengenyampingkan urusan politik dan menjadi oposisi atau pengkritik keras kepada negara sangat dilarang dan tidak dianjurkan, hal ini sangat berbeda dengan kelompok-kelompok lain yang menjalankan paham ideologi warisan Ikhwanul Muslimin. Komunitas salafy juga banyak kita temui di kajian online atau offline.

Dari berbagai pergerakan dan infiltrasi di atas yang beriringan dengan pemanfaatan teknologi menjadikan banyak perubahan budaya dan perilaku keagamaan yang tidak lagi tradisional akan tetapi lebih terbuka dan dinamis. Keterbukaan tersebut bukan hanya berdampak positif bagi keberlangsungan agama tetapi juga mengancam otoritas keagamaan tradisional bahkan bagi beberapa kelompok media sosial dimanfaatkan menjadi cara baru untuk memasukan paham ideologi radikalisme hingga menyebarkan ide ekstrimisme. Pemanfaatan media-media yang mudah di jangkau masyarakat seperti Facebook, YouTube, Twitter, blog hingga aplikasi layanan pesan gratis seperti WhatsApp dijadikan alat bagi kelompok teroris dan Islam transnasional untuk melakukan propaganda, mendapatkan pengaruh dan menjaring keanggotan warga di jejaring sosial. Pola strategi gerakan yang lebih canggih ini bukan hanya dilakukan oleh kelompok teroris ekstrimis saja, seperti ISIS, JI, dan JAT, melainkan juga berbagai organisasi Islam transnasional, misalnya Jamaah Salafi, HTI, dan Harakah Tarbiyah. ${ }^{34}$

${ }^{33} \mathrm{https}: / /$ nasional.kompas.com.

${ }^{34}$ Khamami Zada, Islam Radikal: Pergulatan Ormas-ormas Islam Garis Keras (Jakarta: Teraju, 2002), 18. 


\section{F. Penutup}

Turki dengan corak politik Islmismenya mengarah pada politik neo-ottomanisme telah merubah kebijakan-kebijakan pemerintahan baik dalam ataupun luar negeri. Ditandai dengan pengubahan Hagia Sophia menjadi Masjid aktif bagi muslim merupakan sebuah tanda akan keseriusan Turki dalam membangun citra kepemimpinan Islam meskipun Turki masih malu-malu untuk mengakui dengan tetap menjalin hubungan diplomasi dengan negara-negara yang bersebrangan dengan ideologinya. Momentum konversi Hagia Sophia dijadikan kedok bagi beberapa kelompok yang berkembang di Indonesia untuk memasukan paham dan meningkatkan eksistensi keIslaman.

Respon kaum muda milenial di era digitalisasi sekarang terkhusus bagi kaum hijrah yang masih mencari jati diri mereka menjadikan media sebagai rujukan utama baik dalam berprilaku keagamaan dan bahkan mencari fatwa. Seiring perkembangan dakwah online yang disisipi kepentingan secara halus media telah mengubah cara pandang dan budaya dalam beragama. Setidaknya terbagi dalam tiga kategori dalam kaitannya dengan politik Turki, kelompok pertama sebagai pengagum sosok Erdogan ditempati oleh kaum milenial nasionalis Islamis yang menjelma sebagian pengikutnya hanya sebatas pengagum disebabkan kesamaan identitas, kemudian yang kedua membentuk kelompok Islamisme konservatif atau disebut dengan kaum salafy yang tidak ikut campur kedalam perpolitikan dan yang ketiga terbentuk menjadi kelompok radikalis dan ekstrimis yang dipengaruhi oleh buzzer Islam radikalis. 
Badudu, JS, Cakrawala Bahasa Indonesia II. Jakarta: Gramedia Pustaka Utama, 1992.

DiMaggio, P., Hargittai, E., Neuman, W. R., \& Robinson, J. P. "Sosial Implication of the Internet", Annual Reviews 2001: 307- 336.

Bubalo, Anthony, dkk, PKS dan Kembarannya Bergiat Jadi demokrat di Indonesia, Mesir, dan Turki, Jakarta: Komunitas Bambu, 2012.

Heidi A. Campbell, Digital Religion Understanding Religious Practice In New Media Worlds, New York: Routledge Taylor \& Francis Group London And New York, 2013.

Khamami Zada, Islam Radikal: Pergulatan Ormas-ormas Islam Garis Keras (Jakarta: Teraju, 2002), 18

Piliang, Y. A, Posrealitas: Realitas Kebudayaan dalam Era Postmetafisika, Yogyakarta: Jalasutra, 2009.

Santana, S, Jurnalisme Kontemporer, Jakarta: Yayasan Obor Indonesia, 2005.

Addini, A, Fenomena Gerakan Hijrah di Kalangan Pemuda Muslim Sebagai Mode Sosial. Journal of Islamic Civilization, 1(2), 2019.

Andraina Ary Fericandra Ambivalensi Implementasi NeoOttomanisme dalam Kebijakan Luar Negeri Turki te hadap Israel 2009-2014, tahun 2016.

Cohen, Andrew Jonathan, Tesis: Arsitektur dalam Agama: Sejarah Hagia Sophia dan proposal untuk mengembalikannya ke ibadah. Universitas Internasional Florida, 2011.

Duraesa, M. A., \& Ahyar, M, Reproliferation of Islamist Movement in Surakarta: Trajectory and Strategy in The Post Democratization Indonesia. DINIKA: Academic Journal of Islamic Studies, 4(2), 2019. 201-224. https://doi.org/10.22515/dinika.v4i2.1637.

Hofheinz, A. "The Internet in the Arab World: Playground for Political Liberalization". International Politics and Society, 2005: 78-96.

Jeanne Francoise, dkk, Jurnal: Perspektif Indonesia Tentang Hagia Sophia, Universitas Muhammadiyah Prof. Dr. HAMKA, Jakarta, Indonesia, 2020. 
Khatib, L, "Communicating Islamic Fundamentalism as Global Citizenship". Journal of Communication Inquiry, 2004: 389-409.

Nafi' Muthohirin, "Radikalisme Islam dan Pergerakannya di Media Sosial", UIN Syarif Hiddayatullah Jakarta, 2015.

Puspitarini, R. C., Kaylan Kebljakan Polltlk Internaslonal: Metode, Teozl \& Stud1 Kasus. Surabaya: CV. Jakad Media Publishing, 202).

Priandoko, "Pengaruh Pemikiran Politik Hasan al-Banna dalam Partai Keadilan Sejahtera Pasca Reformasi di Indonesia Tahun 1998-2014" Fakultas Ilmu Sosial dan Ilmu Politik Universitas Riau, 2015.

M. Arfan Mu'ammar "Kritik Terhadap Sekularisasi Turki Telaah Historis Transformasi Turki Usmani" 2016 Pascasarjana Universitas Muhammadiyah Surabaya.

Nabhan Aiqani, Menguatnya Popularitas Turki di Indonesia: Faktor Ikhwanul Muslimin sebagai Identitas Kolektif Ilmu Hubungan Internasional Universitas Andalas, 2018.

Rahman Nurdin Saleh, Arah Politik Gerakan Islam pada DuaZaman: Studi Komparatif antara Ikhwanul Muslimin di Mesir dan Partai Keadilan Sejahtera di Indonesia, 2016.

Situmorang, J. R, "Pemanfaatan Internet sebagai New Media dalam bidang Politik, Bisnis, Pendidikan dan Sosial Budaya," Jurnal Administrasi Bisnis, Vol.8,No.1, 2012.

Saputra, S., Pujiati, \& Simanihuruk, M, Pengemasan Ideologi dalam Gerakan Hijrah (Studi Kasus Gerakan Komunitas Sahabat Hijrahkuu di Medan), Civic-Culture: Jurnal Ilmu Pendidikan PKn dan Sosial Budaya, 2020.

Umi Qodarsasi, Melina Nurul Khofifah, Hagia Sophia Dan Kebangkitan Politik Islam Di Turki, Institut Agama Islam Negeri (IAIN ) Kudus, 2020.

Umut Uzer, Conservative Narrative: A Contemporary NeoOttomanist Approach to Turkish Politics", 2020.

Yunus, A. H, Hijrah: Pemaknaan dan Alasan Mentransformasikan Diri Secara Spiritual di Kalangan Mahasiswa. Jurnal Emik, 2(1), Tahu n 2019.

Zulhazmi, A. Z., \& Hastuti, D. A. S. (2018). Da'Wa, Muslim Millennials and Social Media. Lentera, 2(2), 121-138. https://doi.org/10.21093/lentera.v2i2.1235.

Mohammad Suryadi Syarif, Jurnal "Indonesian Perspective on Hagia Sophia" Dosen studi Pascasarjana di Universitas Muhammadiyah 2020. 
Kamilah. Skripsi tentang "Peranan Mustafa Kemal Ataturk dalam Modernisasi Turki Tahun 1923-1938" 2011.

Isil Sariyuce and Emma Reynolds, 2020, 26 Juli, Turkey's Erdogan orders the conversion of Hagia Sophia back into a mosque, $\mathrm{CNN}$ Diakses dari: https://edition.cnn.com/2020/07/10/europe/hagia-sophiamosque-turkey-intl/index.html

Eka Yudha (Minggu, 26 Juli 2020 ) Turki dan Yunani Saling Sindir Usai Salat Jumat di Hagia Sophia, 2020. Diakses dari https://dunia.tempo.co/read/1369340/Turki-danyunani-saling-sindir-usai-salat-jumat-di-hagia-sophia

Kompas.com 2017, HTI Resmi dibubarkan pemerintah, diakses dari

https://nasional.kompas.com/read/2017/07/19/10180761/ hti-resmi-dibubarkan-pemerintah?page=all

Kompas.com Turki Resmi Jadikan Hagia Sophia Masjid, NegaraNegara Ini Menentang, 11 juli 2020. Diakses pada:

https://www.kompas.tv/article/93130/turki-resmi-jadikan-hagiasophia-masjid-negara-negara-ini menetang\#: :text=KOMPAS.TV\%20\%2D\%20Presiden $\% 20$ Turki\%2C,museum\%20yang\%20dikeluarkan\%20pa da\%201935. 